\title{
1 \\ On studying policy successes in Australia and New Zealand
}

\author{
Joannah Luetjens, Michael Mintrom and Paul 't Hart'
}

Through public policies, governments have enormous potential to shape the lives of their citizens. Actions taken at any given time can affect both present conditions and future trajectories. Much is at stake when new public policies are forged or when established ones are reformed. Since the development of Australia and New Zealand in the nineteenth century as outposts of the British Empire, successive governments in both countries have progressively shaped independent identities for these nations and their populations. Australia and New Zealand have emerged as nations willing to engage in much public policy experimentation. As a result, both countries have together amassed a rich body of experience in public policy development that resonates with policy developments in Europe, Scandinavia and North America. Along the way, members of the policymaking communities in both countries have kept up a lively, mutually beneficial trade in policy ideas, policy emulation and lesson-drawing.

1 The authors wish to acknowledge the considerable overlap between this introductory chapter and the introduction in the companion volume (Mallory Compton and Paul 't Hart, eds, Great Policy Successes, Oxford University Press, 2019). 


\section{Why this book, why now?}

For those wanting to know how public policy is made and how it evolves from aspirations and ideas expressed in speeches and documents to tangible social outcomes (or lack thereof), the 1970s produced some classic accounts, which are now established in academic curriculums and the canon of academic research worldwide. The two best-known works from this foundational set of policy studies are Jeffrey Pressman and Aaron Wildavsky's Implementation (1973) and Peter Hall's Great Planning Disasters (1982). The former is an intensive, book-length case study of how a federal employment promotion policy launched in the United States with a great sense of urgency and momentum played out on the ground with very limited success in Oakland, California. The latter volume presents a collection of public policy failures from around the Anglosphere: 'positive' planning disasters (adopted planning projects that ran into cost escalation, underperformance, withdrawal of political support or unintended consequences so big they completely dwarfed the intended aims) and 'negative' planning disasters (instances in which pressing public problems were not addressed because of political stalemate).

Taken together, these studies were emblematic of an era in which the alleged 'ungovernability' of Western societies and their welfare states was a dominant theme (Crozier et al. 1975; Rose 1979; Offe 1984). Having seized a much more prominent role in public life after World War II, Western governments were ambitious to achieve planned change, but internal complexities and the vagaries of democratic political decisionmaking often thwarted those ambitions. Generations of public policy and public administration students were steeped in pessimistic diagnoses from these classic studies. Waves of similar studies followed in the 1990s (Butler et al. 1994; Bovens and 't Hart 1996; Gray and 't Hart 1998) and more recently (Allern and Pollack 2012; Crewe and King 2013; Light 2014; Schuck 2014; Oppermann and Spencer 2016). These works imply that much of the time governments are up to no good, incompetent, politically paralysed and prone to overreach (e.g. Scott 1998; Schuck 2014).

And yet, in many parts of the world, including Australia and New Zealand, across many public policy domains, the bulk of public projects, programs and services perform not so badly at all, and sometimes even highly successfully (Goderis 2015). These cases are chronically underexposed and understudied. Major policy accomplishments, striking 
performance in difficult circumstances and thousands of taken-forgranted everyday forms of effective public value creation by and through governments are not deemed newsworthy. They cannot be exploited for political gain by oppositions and critics of incumbent officeholders. Curiously, academic students of public policy have had almost nothing to say about them (cf. Bovens et al. 2001; McConnell 2010; Moore 2013). This is despite vigorous calls to recognise the major and often hidden and unacknowledged contributions of governments to successes claimed by and widely attributed to now revered companies such as Google (Mazzucato 2013).

We cannot properly 'see', let alone recognise and explain, variations in government performance when media, political and academic discourses alike are saturated with accounts of their shortcomings and failures but are next to silent on contributions and successes. The dominance of the language of disappointment, incompetence, failure, unintended consequences, alienation, corruption, disenchantment and crisis in public and academic discourse about government, politics and public policy is not inconsequential (Hay 2007). It risks creating self-fulfilling prophecies in the way we look at, talk about, think of, evaluate and emotionally relate to public institutions. The current ascent of 'antisystem' populist politicians speaks volumes, and the message is hardly reassuring. The 'declinist' discourse of the current age has permeated our thinking about government and public policy. It prevents us from seeing, acknowledging and learning from past and present instances of highly effective and highly valued public policymaking.

This book is intended to help turn that tide. It aims to reset the agenda for teaching, research and dialogue on public policy performance in Australia and New Zealand. This is done through a set of in-depth case studies of the genesis and evolution of standout public policy accomplishments, across a range of sectors and challenges. Through these accounts, we engage with the conceptual, methodological and theoretical challenges that have plagued extant research, seeking to evaluate, explain and design successful public policy.

There are many ways to 'get at' questions of public policy success. Existing conceptual and comparative studies of public policy success (Bovens et al. 2001; Patashnik 2008; McConnell 2010) suggest that achieving it involves two major tasks: craft work, which is devising, adopting and implementing programs and reforms that have a meaningful impact 
on the public issues giving rise to their existence; and political workforming and maintaining coalitions of stakeholders to persuasively propagate these programs. This political work extends to nurturing and protecting elite and public perceptions of the policy's or program's ideology, intent, instruments, implementation and impact during the often long and arduous road from ideas to outcomes. Success must be experienced and actively communicated or it will go unnoticed and underappreciated. The present volume aims to shed light on how these two fundamental tasks-program and process design, and coalitionbuilding and reputation management-are being taken up and carried out to effect highly successful public policymaking.

This collection of cases of successful public policy follows in the footsteps of the studies of failure developed by Peter Hall and, before him, Jeffrey Pressman and Aaron Wildavsky. Descriptively, these cases are important in their own right; rich narratives of instances of policy success in a variety of contexts can help to increase awareness of the fact that government and public policy actually work remarkably well at least some of the time. Analytically, we have encouraged the authors of these cases to emulate powerful exemplars in the study of successful, high-performing, highly reputed public organisations (Selznick 1949; Kaufman 1960; Carpenter 2001; Goodsell 2011). This has allowed us to employ 'soft induction' to identify commonalities and mechanisms at play and present these as a foundation for future policy designers and researchers.

\section{How do we know a 'successful public policy' when we see one?}

Policy successes, like policy failures, are in the eye of the beholder. They are not mere facts but stories. Undoubtedly, 'events'-real impacts on real people-are a necessary condition for their occurrence. But, in the end, policy successes do not so much occur; they are made. To claim that $\mathrm{X}$ - a public policy, program or project-is a 'success' is effectively an act of interpretation, indeed of framing. To say this in a public capacity and in a public forum makes it an inherently political act. It amounts to giving a strong vote of confidence to certain acts and practices of governance. In effect, it singles them out, elevates them and validates them. For such an act to be consequential it needs to stick; others need to become convinced of its truth and need to emulate it. The claim ' $\mathrm{X}$ is a success' 
needs to become a more widely accepted and shared narrative. When it does, it becomes performative: X looks better and better because so many say so, so often. When the narrative endures, $\mathrm{X}$ becomes enshrined in collective memory through repeated retelling and other rituals. Examples of the latter include the conferral of awards on people or organisations associated with $\mathrm{X}$, who then subsequently receive invitations to come before captive audiences to spread the word; the high place that X occupies in rankings; and the favourable judgements of $\mathrm{X}$ by official arbiters of public value in a society, such as audit agencies or watchdog bodies, not to mention the court of public opinion. Once they have achieved iconic status, success tales-no matter how selective and biased certain critics and soft voices may claim them to be (see, for example, Schram and Soss 2001) — serve as important artefacts in the construction of the self-images and reputational claims of the policymakers, governments, agencies and societal stakeholders that credibly claim authorship of their making and preservation (Van Assche et al. 2011).

We must tread carefully in this treacherous terrain. We needed to arrive at a transparent and widely applicable conceptualisation of 'policy success' to be deployed throughout the cases in this volume and a basic set of descriptive research tools allowing us to spot and characterise the 'successes' presented here. To get to that point, we surmise that policy assessment is necessarily a multidimensional, multiperspective and political process. At the most basic level, we distinguish between the programmatic performance of a policy and its political legitimacy. Successful programmatic performance is essentially about designing smart programs that will really have an impact on the issues they are supposed to tackle and delivering those programs in such a manner that they produce valuable social outcomes. Successful attainment of political legitimacy for a policy involves the extent to which both the social outcomes of policy interventions and the manner in which they are achieved are seen as appropriate by relevant stakeholders and accountability forums in view of the systemic values in which they are embedded (Fischer 1995; Hough et al. 2010).

The relationship between these two dimensions of policy evaluation is not straightforward. There can be (and often are) asymmetries: politically popular policies are not necessarily programmatically effective or efficient, and vice versa. Moreover, there is not necessarily a shared normative and informational basis on which different actors in governance processes assess their performance, legitimacy and endurance (Bovens et al. 2001). Many factors influence the beliefs and practices through which people 
form judgements about governance. Different stakeholders have different vantage points, values and interests with regard to a policy, and thus may experience and assess it differently. An appeal to 'the facts' does not necessarily help to settle these differences. Indeed, like policymaking, policy evaluation occurs in a context of multiple, often competing, cultural and political frames and narratives, each of which privileges some facts and considerations over others (Hajer and Wagenaar 2003). Policy evaluation is inherently political in its approach and implications, no matter how deep the espoused commitment to scientific rigour of many of its practitioners. This is not something we can get around; it is something we have to acknowledge and be mindful of without sliding into thinking that it is all and only political—and that, therefore, 'anything goes' when it comes to assessing the success or otherwise of a policy (Bovens et al. 2006).

Allan McConnell (2010) added a third dimension to Mark Bovens and Paul 't Hart's programmatic-political dichotomy, and produced a threedimensional assessment map that we have adapted for our purposes (cf. Newman 2014):

- Programmatic assessment: This is 'classic' evaluation research focus on a policy's goals, the theory of change underpinning it and the selection of the policy instruments it deploys_-all culminating in judgements about the degree to which a policy achieves valuable impacts.

- Process assessment: The focus here is on how the processes of policy design, decision-making and delivery are organised and managed, and whether these processes contribute to not only the policy's technical problem-solving capacity (effectiveness and efficiency), but also its social appropriateness and in particular the sense of procedural justice among key stakeholders and the wider public (Van den Bos et al. 2014).

- Political assessment: This dimension assesses the degree to which the policymakers and agencies involved in driving and delivering the policy are able to build and maintain fungible political coalitions supporting it, and the degree to which their association with it enhances their reputations. In other words, it examines both the political requirements for policy success and the distribution of political costs and benefits among the actors associated with it. 
Table 1.1 A policy success assessment map

\begin{tabular}{|c|c|c|}
\hline $\begin{array}{l}\text { I. Programmatic } \\
\text { assessment: Purposeful } \\
\text { and valued action }\end{array}$ & $\begin{array}{l}\text { II. Process assessment: } \\
\text { Thoughtful and fair } \\
\text { policymaking practices }\end{array}$ & $\begin{array}{l}\text { III. Political assessment: } \\
\text { Stakeholder and public } \\
\text { legitimacy for the policy }\end{array}$ \\
\hline $\begin{array}{l}\text { A well-developed and } \\
\text { empirically feasible public } \\
\text { value proposition and } \\
\text { theory of change (ends- } \\
\text { means relationships) } \\
\text { underpins the policy } \\
\text { Achievement of } \\
\text { (or considerable } \\
\text { momentum towards) } \\
\text { the policy's intended } \\
\text { and/or other beneficial } \\
\text { social outcomes } \\
\text { Costs/benefits associated } \\
\text { with the policy are } \\
\text { distributed equitably } \\
\text { in society }\end{array}$ & $\begin{array}{l}\text { The policy process allows } \\
\text { for robust deliberation about } \\
\text { and thoughtful consideration } \\
\text { of: the relevant values and } \\
\text { interests; the hierarchy } \\
\text { of goals and objectives; } \\
\text { contextual constraints; } \\
\text { the (mix of) policy } \\
\text { instruments; and the } \\
\text { institutional arrangements } \\
\text { and capacities necessary } \\
\text { for effective policy } \\
\text { implementation } \\
\text { Stakeholders } \\
\text { overwhelmingly experience } \\
\text { the making and/or delivery } \\
\text { of policy as just and fair }\end{array}$ & $\begin{array}{l}\text { A relatively broad and } \\
\text { deep political coalition } \\
\text { supports the policy's value } \\
\text { proposition, instruments } \\
\text { and current results } \\
\text { Association with the policy } \\
\text { enhances the political } \\
\text { capital of the responsible } \\
\text { policymakers } \\
\text { Association with the policy } \\
\text { enhances the organisational } \\
\text { reputation of the relevant } \\
\text { public agencies }\end{array}$ \\
\hline \multicolumn{3}{|l|}{ IV. Temporal assessment } \\
\hline \multicolumn{3}{|c|}{$\begin{array}{l}\text { Endurance of the policy's value proposition (i.e. the proposed 'high-level' intent } \\
\text { and commitment underpinning its rationale and design, combined with the } \\
\text { flexible adaptation of its 'on-the-ground' and 'programmatic' features to changing } \\
\text { circumstances and in relation to performance feedback) }\end{array}$} \\
\hline \multicolumn{3}{|c|}{$\begin{array}{l}\text { Degree to which the policy's programmatic, process and political performance } \\
\text { is maintained over time }\end{array}$} \\
\hline \multicolumn{3}{|c|}{ Degree to which the policy confers legitimacy on the broader political system } \\
\hline
\end{tabular}

Table 1.1 presents our map for assessing policy success. As the table demonstrates, we have added a fourth dimension to McConnell's threedimensional assessment framework: success over time. This follows from the third assumption underpinning this volume-namely, that the success or otherwise of a public policy, program or project should be studied not as a snapshot but as a film. A policy's success is therefore also to be assessed in terms of how performance and legitimacy develop over time as a policy advances from proposal, design and delivery to impact. It is also important to interpret the extent to which elements of the assessment of the policy - that is, its process, impact and political legitimacy - evolve over time. Contexts change, unintended consequences emerge and surprises are thrown at history. Successful policies are those that adapt to these developments through 'dynamic conservatism' in program (re)design and learning-based program delivery. Success can also be a function of political astuteness in the safeguarding of supporting coalitions and the maintenance of a policy's public reputation and legitimacy. 
Building on both these assumptions, we propose the following definition of a successful public policy:

A policy is a complete success to the extent that: a) it demonstrably creates widely valued social outcomes; through b) design, decision-making and delivery processes that enhance both its problem-solving capacity and its political legitimacy; and it c) sustains this performance for a considerable period even in the face of changing circumstances.

This conceptualisation formed the basis of an assessment framework that has given the authors contributing to this volume a consistent set of perspectives and criteria to consider in analysing their cases. By articulating specific elements of each dimension of success-programmatic, process and political-in unambiguous and conceptually distinct terms, this framework lends a structure to case study authors in both contemporaneous evaluation and dynamic consideration of policy developments over time.

\section{Studying policy success: Methodological considerations}

Having established a working method for 'seeing' policy success in operational terms, we next review the broader methodological challenges faced by anyone interested in understanding policy success. Before we do so, it is important to point out that researchers have approached this task in a wide range of ways. Broadly, three types of approaches can be discerned.

At the macro level, there are studies of overall government performance. These usually take the form of cross-national and cross-regional datasets. Some researchers focus on the input and throughput side of governmentfor example, the quality of government dataset that captures cross-national differences in the trustworthiness, reliability, impartiality, incorruptibility and competence of public institutions (Rothstein 2011). Of more direct relevance from a policy success point of view are datasets and balanced scorecard exercises focusing on aggregate governance outputs, outcomes and productivity in specific domains of government activity, performed and propagated by, for example, the World Bank, the Organisation for Economic Co-operation and Development (OECD) and many national audit offices and government think tanks (Goderis 2015). At the meso level, social problem, policy domain and program evaluation specialists regularly 
examine populations of cases to identify areas of high performance. Examples include crime prevention, adult literacy, refugee settlement and early childhood education programs. Drawing on this evidence, these analysts then examine 'what works' and assess whether these programs or key features of them can be replicated and transferred to other contexts (e.g. Isaacs 2008; Blunch 2017; Weisburd et al. 2017; see also Lundin et al. 2015). Finally, at the micro level, researchers probe deeply into the context, design, decision-making, implementation, reception, assessment and evolution of single or a limited number of policies or programs, as Peter Hall in his study and Jeffrey Pressman and Aaron Wildavsky in theirs, for instance.

Each of these three approaches comes with a distinctive set of potential strengths and weaknesses. The macro studies offer the big-picture, helicopter perspective of linkages between governance activities and social outcomes. They offer good insight into the social and economic consequences of the design of public institutions and the effect of public spending patterns. They generally offer no or limited insight into what occurs in the 'black box' in which these linkages take shape.

The meso studies drill down to the level of programs and come closer to establishing the nature of the links between their inputs, throughputs, outputs and outcomes. Structured, focused comparative designs that at the same time control for institutional and contextual factors can yield richer pictures of 'what works'. A key limitation of these population comparisons is that considerations of parsimony limit the depth of attention that is given to the nuances of context, chance, choice, communication, cooperation and conflict within each of the units of analysis. As a result, it often proves difficult for meso studies to convincingly explain why things work well or not so well.

That is precisely the main potential strength of case study designs. These micro-level qualitative studies have the biggest potential of opening the black box and examining the actor constellations, institutional arrangements, power relationships, leadership and decision-making processes and the realities of frontline service delivery involved. Analysts working in this tradition have a better shot at reconstructing the constellations of factors and social mechanisms that converge to produce policy successes. This hypothesis-generating potential of micro studies is significantly enhanced when they are conducted in a fashion that allows for systematic comparison across cases. Yet, efforts to empirically 
generalise their findings must be done cautiously as there always remains the possibility that a similar convergence of factors and social mechanisms in other, unexamined contexts might have yielded different outcomes.

This volume is set in the micro tradition. We have sought to deliver on its potential strengths in hypothesis generation and identification of emerging patterns across cases, while navigating the inherent limitations of the micro tradition and its methodological challenges. Some of these are generic and also challenge macro and meso approaches, while some are specific to the micro genre of success studies. We will now briefly discuss those methodological challenges.

\section{A constructed, political concept}

Success is not an event, but a label people use to express a value judgement about events. A policy success does not come prelabelled in the world; it is constructed in the stories we tell and the stories we come to hold true about a policy. These stories are seldom self-evident, consistent or uniformly shared. Public policies themselves are the product of 'pulling and hauling', 'puzzling and powering' between multiple parties inside and outside government. The words we use to make meaning of policy matter. Meaning-making is inherently political in that-intentionally or not-meanings ascribed to policies can have a bearing on 'who gets what, when and how' (Lasswell 1936; Stone 2001). The processes of arguing, bargaining and influencing that occur in the agenda-setting and design stages of a policy in fact permeate the entire policy cycle. They do not stop when policymakers, legislatures, auditors or even independent researchers pause to take stock and pass a verdict on a policy or program.

Persuasive though we hope it has been, the conceptual points we have made in the preceding pages are not about to be universally embraced any time soon. All the authors of the case studies presented in this volume have been asked to work with these conceptual tools, following a template for inquiry. However, not only do they come to the project with their own preconceptions, but also they in turn have to rely on textual and human sources in their research that are part of the political fray of the case at hand. We advise readers therefore not to take any of the labels and interpretations concerning a policy's alleged 'success' for granted, but to constantly question what frames - and whose frames-are at work here and examine by what evidence they are underpinned. 


\section{Case selection}

Conceptual definition of the outcome of interest-policy success-is just the start of the battle for valid inference. With defined concepts in hand, a researcher must next choose an appropriate sample from which to draw conclusions. If the first lesson in any undergraduate research methods course is that 'correlation is not causation', the second is sure to be in the spirit of 'thou shalt not select on the dependent variable'. Although criteria for sample selection vary across the quantitative-qualitative divide (Mahoney and Goertz 2006), it is agreed that the cases you choose affect the answers you get (Geddes 2003). The message is hammered into the minds of young scholars that - for reasons that are well understoodselecting cases based on the value of the dependent variable can profoundly bias statistical findings, fouling generalisation and average effect estimation (e.g. Heckman 1976). And yet, how a researcher selects their cases should be driven principally by the research question. Case selection should be a deliberate and well-considered procedure tailored to the specific research question at hand and the type of explanation sought (King et al. 1994; Brady and Collier 2010). There are defensible reasons to violate the dependent variable rule and select only or mostly 'positive' cases (Brady and Collier 2010). In this multiple-case project, we are not seeking causal explanation or formal comparison. Nor do we endeavour to arrive at universal generalisability of our findings. We are, instead, interested in documenting, understanding and problematising the actors, contexts, ideas and institutions that interact to produce the outcome of value: successful public policy. We believe that exploratory work of this kind is a fundamental precursor to quantitative studies that could usefully identify and test the strength of empirical regularities contributing to policy successes. Our case study selection decisions were made with these considerations in mind.

Our detailed case studies of highly successful public policies in Australia and New Zealand have been carefully chosen after intensive consultation with panels of public policy experts in both countries. The expert panels included professors of public policy, heads of think tanks, senior public policy practitioners and former secretaries of the Treasury, the Department of the Prime Minister and Cabinet and other central agencies. Experts were asked to list up to five cases from their country that they considered to be exemplary examples of successful policies and were provided with the operational definition of a successful policy (see above). Experts were also asked to provide the names of two other people they believed should be approached. This was to triangulate suggestions across expert respondents. 
In total, 23 experts participated in the process. Once the initial lists of successful policies were created, they were returned to the country expert panels for confirmation and comment.

The selection method was designed to be both replicable and reliablethat is, we selected our cases using a process of consultation that other researchers could easily replicate. Further, we are confident that if others did replicate our process - even if they began with a different initial set of experts to consult - they would end up with a list of cases that correlated highly with the list we developed. We believe we have chosen the most salient examples of successful public policy from both countries over the past few decades.

Following our consultation process and the collation of the list of successful public policies, we invited potential authors to write on the selected cases. Authors were chosen based on their senior work experience or their academic research expertise. Most of the authors in this volume were matched to cases on which they already held extensive knowledge. Many have previously published work relating to these public policies, although the treatment of them specifically as cases of successful public policy was a unique experience in every case.

\section{Moving pictures: Time and policy assessment}

In assessing policy outcomes, where one stands often depends on when one looks, and with what kind of temporal perspective in mind. With the passing of time, public and political perceptions of the processes and outcomes of a public policy can shift. A case in point is the construction of the Sydney Opera House (1954-73). During the conflict-ridden and traumatic implementation phase of this highly adventurous architectural project, it was considered a major fiasco. Construction took 10 years longer than initially planned, and the costs exploded from the 1954 tender of A \$7 million to well over A \$100 million on completion in 1973. Significantly, the architect walked out midcourse following a series of confrontations with an increasingly sceptical Minister of Public Works whose party had won the NSW election that year promising to rein in the 'out of control' Opera House project. Not surprisingly, Peter Hall (1982) dutifully included the Opera House project in his Great Planning Disasters, researched in the mid-1970s and first published in 1979. 
Yet this failure frame did not last. During the late 1970s and the 1980s, the Opera House became a major tourist attraction, and it has since evolved into a globally recognised architectural icon. The original budget overruns thus came to be viewed in a different light. The fact that most of the building costs had not come from the public purse but from a series of designated public lotteries-long wilfully overlooked in the political debate-made a comeback. More importantly, later generations hardly cared about the original costs, as the benefits - both monetary and cultural-had so clearly outstripped them. Over time, the weight accorded to 'project management' criteria-where success is defined as delivering according to specifications, on time and within budgetreceded. The dominant evaluative lenses became strategic, macroeconomic and symbolic.

A prime source of analytical biases therefore involves the variety of possible time horizons and the registration of the various effects policies have over time. The objectives of policies may vary in terms of their temporal scope (in economic policy planning, a differentiation between short-term, medium-term and long-term policies is quite common) and temporal quality (unique/nonrecurrent versus permanent/iterative policies). This affects the timing and nature of assessments about their effects when implemented. Policymakers are in fact continuously vacillating between different time horizons in setting priorities, allocating budgets and making decisions. At the same time, many elected officials and others subject to the vagaries of the electoral cycle are predisposed to judge policy proposals or feedback about past policies first and foremost in terms of their shortterm political implications.

Short-term effects are also more easily registered than long-term effects, which are likely to become intertwined with other phenomena in complex and often unintended ways. Moreover, short-term and long-term effects may in some cases be at odds with one another, the latter reversing or neutralising the former. In general, the longer the time frame used for the assessment of policy outcomes, the bigger is the scope for controversy about their meaning and evaluation. Similarly, the processes and outcomes of policies aimed at nonrecurrent outcomes (such as development of specific infrastructural assets, successful hosting of sporting events or global summits or responses to a natural disaster) tend to be more easily grasped than those of policies with iterative objectives that are constantly being renegotiated and adapted by different participants and in the face of changing circumstances. In evaluating efforts to significantly change 
the behaviour of large numbers of people in particular, a limited time frame is inappropriate because it neglects both the severity of the initial administrative problems and the possibility of learning by doing.

\section{An overview of the volume}

Having discussed our rationale for studying policy successes and how we identified cases for inclusion in this volume, we now review the topics of the selected cases, the common set of analytical questions we asked authors to work through in their chapters and some emerging patterns we have observed across the cases.

\section{The cases}

This volume contains 20 chapter-length studies of specific cases of successful public policy from Australia and New Zealand. Of these, 12 come from Australia and eight from New Zealand. The cases come from a broad range of policy areas. Economic policy is represented by six chapters-four from Australia and two from New Zealand. Two of the Australian cases relate to the Global Financial Crisis (GFC) of 2008-09 and responses to it. Promoting greater market efficiency is treated in one case each from Australia and New Zealand. The goods and services tax (GST) was proposed as a policy success in both Australia and New Zealand. We chose to have this success case portrayed using the Australian experience, although the New Zealand experience with the GST is mentioned in the chapter on the economic reforms of the 1980s. Health policy is represented by three chapters. There is a chapter on Medicare in Australia and another on the Accident Compensation Corporation in New Zealand. There is also a chapter on Australia's responses to the human immunodeficiency virus/acquired immune deficiency syndrome (HIV/AIDS) epidemic. Education policy is treated in two chapters-one devoted to the funding of higher education in Australia through student loans and the other to New Zealand's policy approaches to promoting early childhood education. In other social policy areas, a chapter is included on child support in Australia and another on national superannuation in New Zealand. Two chapters relate to policies in New Zealand addressing issues of high importance to Māori and the pursuit of biculturalism. The first 
considers the processes to address historical injustices through Treaty of Waitangi settlements, while the second considers how Whānau Ora has been pursued to improve the wellbeing of Māori families in New Zealand.

Beyond these chapters, we have several that cover a range of other policy topics. There is one on urban public policy that explores efforts to make Melbourne more liveable. Another chapter explores the success of gun control efforts in Australia. Continuing the theme of addressing social problems, a further chapter explores efforts to reduce the appeal of smoking to young Australians. Infrastructure policy is represented in the cases by a chapter on the creation of water markets in Australia. In the realm of foreign policy, we include a chapter on New Zealand's nuclearfree stance.

\section{Analytical questions}

The narratives presented in each of the following chapters provide insights into how success occurred in each case. Each chapter has been designed to answer the guiding questions set out in Box 1.1. While we did not require chapter authors to answer all of these questions exactly as they have been posed, we did ask that the general line of inquiry be closely followed. This has resulted in chapters that tell their own stories in an accessible fashion, while also relating in clear thematic ways to the other chapters in the volume.

\section{Box 1.1 Guiding questions for case analysis}

1. What is this case about and why is it included in this volume? What, in other words, is its fundamental 'claim to success' in terms of the definition and the assessment dimensions contained in Table 1.1?

2. What were the social, political and institutional contexts in which the policy (program, project, initiative) was developed?

3. What specific challenges was it seeking to tackle; what, if any, specific aims did it seek to achieve?

4. Who were the policy's main drivers and stewards, and how did they raise and maintain support for the policy?

5. How did the policy design process - the progression from ambitions and ideas to plans and instruments-unfold, and what factors shaped it most?

6. How did the political decision-making process leading up to its adoption - the progression from proposals (bills, proposals) to commitments (laws, budgets) unfold, and what factors shaped it most?

7. How did the implementation process - 'what happens after a bill becomes a law' (Bardach 1977)-unfold, and what factors shaped it most? 
8. How did the legitimacy of the policy - the political and public support garneredunfold, and what factors shaped it most?

9. How did changes over time in the operating or political context (such as government turnover, fiscal positions, critical incidents) affect:

a. the policy's central features

b. levels of popular support or perceived legitimacy?

10. What, overall, can policy analysts and policy actors learn from this instance of policy success:

a. How have the lessons learned evolved over time? Has this case always been a 'success' and, if not, what changed?

b. How likely is this case to remain a 'success' in the future? What are potential future problems with this policy case or a similar class of cases?

11. What unique factors might limit how broadly the lessons from this case can be applied (in terms of political, social or economic contexts or policy domain, etc.)?

The result is a diverse set of cases explored with a common set of reference points. This approach offers many opportunities for comparisons to be drawn between various groups of chapters and for themes to be drawn out from across the whole set. Next, we offer one way of reading these chapters thematically, by noting some of the emerging patterns that have struck us as we have worked closely with these chapters.

\section{How success happens: Emerging patterns}

Across the diverse set of cases included in this volume, a variety of emerging patterns can be detected and highlighted. Here, we note six, each of which appears across four or more of the cases.

\section{Pattern one: Targeting and framing}

Successful public policies tend to address a problem that was well defined and broadly acknowledged at the outset of the policy development process. Take, for example, the introduction of the Higher Education Contribution Scheme (HECS) in Australia. There was a strong desire to expand the number of school-leavers attending university. However, there was a concern that government subsidisation of university attendance served too much as a benefit to the middle class. The student loan scheme was devised in such a way that access to university was expanded while ensuring that the flow of benefits was not skewed towards more privileged groups in society. Likewise, Australia's National Competition Policy 
was devised to acknowledge costs to the Australian economy created by regulations that protected certain industries, exclusive government ownership or some combination of the two. The industries that were targeted managed major network utilities providing Australia's gas and electricity infrastructure as well as water and transport. The policy enjoyed support from the Commonwealth Government and governments in the states and territories. Many other examples are found throughout this volume of policies responding to problems that were broadly acknowledged and well defined.

\section{Pattern two: Ripening, not running}

The proposed policy solution had been carefully developed, debated and refined over a reasonable period. There is no particular pattern as to how this careful policy development takes place. In the case of New Zealand's Accident Compensation Corporation, the policy that gave form to this entity had its genesis in the report of a royal commission of inquiry. There was nothing remarkable about the royal commission itself; however, the report was presented in a fashion that placed unwavering focus on the wellbeing of the affected population while also giving appropriate consideration to concerns about efficiency. The report was exceptionally clear in presenting the case for policy change. This theme is reinforced in the chapter on the economic reforms in New Zealand in the 1980s, when Treasury advice was devised over a lengthy period and in a way that placed significant weight on intellectual coherence. Across the Australian cases in this volume, multiple examples are provided of successful public policies having their origins in conceptually coherent, evidence-informed advice, the best of which also paid careful attention to issues of effective implementation. This theme is strongly on display in the cases on HECS and child support. It is echoed in the cases on Medicare and gun control, among others.

\section{Pattern three: Champions and stewards}

As we might expect from the literature on policy entrepreneurship, often strong support from policy champions came when the policies were first being introduced. This dynamic is seen, for example, in the cases of HECS and gun control in Australia. In New Zealand, the actions of policy champions were very clearly on display during the period of economic reform in the 1980s. It is also interesting to observe that sometimes these policy champions might emerge after the policy has been 
adopted. In this sense, the work of these champions-and the supportive coalition-becomes most crucial during the implementation phase. A powerful example of this is provided by the New Zealand case of Treaty of Waitangi settlements. Here, a policy position asserted by a Labour Party government was maintained by the incoming National Party government. But, most significantly, the actions of the responsible minister in that government, who led treaty settlements for many years, made the whole process a success. All of those actions were concerned with implementing and embedding the treaty settlement institutions and processes, which would manage the reconciliation efforts. This support for the policy is remarkable, given that it frequently was the focus of public disquiet about the cost to taxpayers of settling treaty grievances.

\section{Pattern four: Strike while the iron is hot}

The policy was viewed as an appropriate response from the government, given the circumstances. In other words, it was the right thing at the right time. This theme is strongly apparent in the case of gun control in Australia. The policy approach had been in development; however, a horrendous mass shooting in Tasmania provided the impetus for rapid moves to bring about policy change in keeping with the development work that had already been done. The policy response in Australia to the HIV/ AIDS epidemic represents another case of a policy being implemented to address a well-documented crisis. The two chapters that discuss aspects of Australia's response to the GFC further illustrate this pattern-a pattern that is also found in several of the New Zealand cases. For example, the Fiscal Responsibility Act was adopted at a time when the government was facing serious debt problems. Evidence of an emerging crisis was clear and the proposed policy was judged to be a broadly appropriate response.

\section{Pattern five: Engineering support}

Many of the policies discussed here enjoyed bipartisan and broad stakeholder support. It is rare for policies to enjoy such support from the outset. We counted the survival of a policy over time as a key indicator of its success, so all of the policies included in this volume have survived changes of government from leadership by the party that gave it initial support to a party that may well have once opposed it. Particularly interesting to observe are cases where support eventually came from quarters where opposition to the policy had at one time been fierce. New Zealand's nuclear-free policy is a good example. It was introduced in 1987 by the 
Labour Government. National Party-led governments subsequently left the policy in place, sensing this was what the public wanted. Even so, in 2005, the leader of the National Party claimed that, if his party was elected to government, the policy would be 'gone by lunchtime'. That caused a lot of controversy. In 2007, on the twentieth anniversary of the law, the National Party's spokesperson for foreign affairs conceded that 'the retention of this legislation that is called iconic, and that is symbolic of our independence of thought and judgment in international affairs, is not in question' (New Zealand Parliament 2007: 9759). This statement makes explicit a common response to successful public policies: with time, they come to be treated as part of the broader fabric of a jurisdiction. The same could be said of the introduction of the GST and of child support and gun control in Australia. Bipartisan support that was often lacking when successful policies were initially adopted came to develop as the policy itself attained a degree of maturity.

\section{Pattern six: Implementation, implementation, implementation}

In a well-received report on why some large government policy initiatives have gone badly wrong in Australia's recent past, Peter Shergold (2015: 4) emphasised that 'policy is only as good as the manner in which it is implemented'. In most of the cases discussed in the present volume, despite their sensible design and the broad support they tended to enjoy, implementation was not at all straightforward. We think this is a surprising finding because past scholarly discussions of policy failure have frequently focused on problems during implementation (Pressman and Wildavsky 1973). In the case of the drive to make Melbourne a more liveable city, there were various challenges that meant implementation occurred in a slow, incremental fashion. Yet, that tough work on a variety of policy fronts finally paid off. When people started to see the benefits of the implementation efforts, assessments of the overall initiative became far more positive. Likewise, the introduction of water markets in Australia had its fair share of frustrations. Indeed, some of those frustrations remain. However, overall, this effort is now viewed as a major policy success. In New Zealand, evidence of success emerging from implementation problems is provided by the case of Whānau Ora. Initially, problems arose because the approach required actors in government to work across silos and to challenge some of their business-as-usual approaches to service 
delivery. And, even while many now view the policy as a success in terms of assisting Māori families under stress, it still attracts criticism from those in society who dislike governments treating different groups differently.

This brief highlighting of patterns across the cases suggests that the presence of certain key factors can increase the likelihood that a public policy will be viewed as a success. Much more could be said. We are aware, too, that the evidence is messy and patterns that are carried strongly across some cases are more muted in others. Nonetheless, it is our contention that drawing out and discussing patterns in this manner can be incredibly useful in supporting the development of critical insights regarding the development, delivery, maintenance and reform of public policies.

\section{Conclusion}

All people involved in the development and implementation of public policy can draw lessons from the past. Those lessons hold the potential to guide practice in highly productive ways. Until recently, efforts to draw lessons from the past have tended to focus on cases of failure. While it is certainly true that important lessons can be drawn from failure, similarly important lessons can be drawn from success. This volume contributes to an emerging body of work that emphasises the value of studying successful public policy. The cases presented here, drawn from Australia and New Zealand, offer a wealth of insights into the factors that appear to support the attainment of expected policy outcomes and that contribute to widely shared views that a policy has been a success.

We have developed this volume with the intention of encouraging further study of successful public policy. The chapter cases included here offer a good representation of well-regarded public policies that have been adopted in Australia and New Zealand over the past few decades. The set of cases is by no means exhaustive. We are aware of other cases that could have been included in this volume. We also anticipate that others will be inspired by the cases here to look for and identify evidence of success in other public policies adopted in Australia, New Zealand and elsewhere. As we noted earlier, several of the authors who contributed to this volume have previously written at length on the public policy cases covered here. However, the approach of exploring these cases as instances of policy success is unique to this volume. We are confident that the cases 
here-and others not represented-could be explored in even greater depth in future works, all with the purpose of identifying mechanisms and practices conducive to policy success.

In sum, we are delighted to introduce this terrific set of cases exploring examples of successful public policy. We are also excited by the agendasetting nature of this volume. We hope it helps to change the frame of professional, public and political debates about government that are so often geared towards its problems and shortcomings. We hope that others will soon take insights emerging from this collective effort as starting points for the development and testing of hypotheses about the conditions that seem to support the emergence of public policies as broadly acknowledged successes. Finally, we hope the studies included here will inspire many emerging and established policy advocates, analysts, designers and implementers to do all they can to ensure the policies on which they work will one day be considered significant successes.

\section{References}

Allern, S. and Pollack, E. (eds) 2012. Scandalous! The mediated construction of political scandals in four Nordic countries. Gothenburg: Nordicom.

Bardach, E. 1977. The Implementation Game. Cambridge, MA: MIT Press.

Blunch, N. H. 2017. 'Adult literacy programs in developing countries.' IZA World of Labor 2017: 374. doi.org/10.15185/izawol.374.

Bovens, M. and 't Hart, P. 1996. Understanding Policy Fiascos. New Brunswick, NJ: Transaction.

Bovens, M., 't Hart, P. and Kuipers, S. 2006. 'The politics of policy evaluation.' In M. Moran and R. E. Goodin (eds), Oxford Handbook of Public Policy. Oxford: Oxford University Press.

Bovens, M., 't Hart, P. and Peters, B. G. (eds) 2001. Success and Failure in Public Governance: A comparative analysis. Cheltenham, UK: Edward Elgar. doi.org/ $10.4337 / 9781843762850$.

Brady, H. E. and Collier, D. 2010. Rethinking Social Inquiry: Diverse tools, shared standards. 2nd edn. Plymouth: Rowman \& Littlefield.

Butler, D., Adonis, A. and Travers, T. 1994. Failure in British Government: The politics of the poll tax. Oxford: Oxford University Press. 


\section{SUCCESSFUL PUBLIC POLICY}

Carpenter, D. 2001. The Forging of Bureaucratic Autonomy: Reputations, networks, and policy innovation in executive agencies, 1862-1928. Princeton, NJ: Princeton University Press.

Crewe, I. and King, A. 2013. The Blunders of Our Governments. London: Oneworld.

Crozier, M. J., Huntington, S. P. and Watanuki, J. 1975. The Crisis of Democracy. New York: NYU Press.

Fischer, F. 1995. Evaluating Public Policy. Chicago: Nelson Hall.

Geddes, B. 2003. Paradigms and Sandcastles: Theory building and research design in comparative politics. Ann Arbor: University of Michigan Press.

Goderis, B. (ed.) 2015. Public Sector Achievement in 36 Countries: A comparative assessment of inputs, outputs and outcomes. The Hague: The Netherlands Institute for Social Research.

Goodsell, C. T. 2011. Mission Mystique: Belief systems in public agencies. Washington, DC: CQ Press.

Gray, P. and 't Hart, P. (eds) 1998. Public Policy Disasters. London: Routledge.

Hajer, M. and Wagenaar, H. (eds) 2003. Deliberative Policy Analysis: Understanding governance in the network society. Cambridge: Cambridge University Press.

Hall, P. 1982. Great Planning Disasters. Berkeley, CA: University of California Press.

Hall, P. 1993. 'Policy paradigms, social learning, and the state: The case of economic policymaking in Britain.' Comparative Politics 25(3): 275-310. doi.org/10.2307/422246.

Hay, C. 2007. Why We Hate Politics. Cambridge: Polity Press.

Heckman, J. A. 1976. 'The common structure of statistical models of truncation, sample selection and limited dependent variables and a simple estimator for such models.' Annals of Economic and Social Measurement 5(4): 475-92.

Hough, M., Jackson, J., Bradford, B., Myhill, A. and Quinton, P. 2010. 'Procedural justice, trust, and institutional legitimacy.' Policing 4(3): 203-10. doi.org/10.1093/police/paq027.

Isaacs, J. 2008. Impacts of Early Childhood Programs. Washington, DC: The Brookings Institution.

Kaufman, H. 1960. The Forest Ranger: A study in administrative behavior. Baltimore: Johns Hopkins University Press. 
Kim, J. Y. 2014. 'Brazil's contribution to a world free of poverty.' The World Bank Opinion, 24 March. Accessed from: www.worldbank.org/en/news/opinion/ 2014/03/24/brazil-contribution-world-without-poverty.

King, G., Keohane, R. O. and Verba, S. 1994. Designing Social Inquiry: Scientific inference in qualitative research. Princeton, NJ: Princeton University Press.

Lasswell, H. D. 1936. Politics: Who gets what, when and how. New York: Whittlesey House.

Light, P. C. 2014. A Cascade of Failures: Why government fails, and how to stop it. Washington, DC: Brookings Institution.

Lundin, B., Öberg, P. and Josefsson, C. 2015. 'Learning from success: Are successful governments role models?' Public Administration 3(3): 733-52. doi.org/10.1111/padm.12162.

McConnell, A. 2010. Understanding Policy Success: Rethinking public policy. Basingstoke, UK: Palgrave Macmillan. doi.org/10.1007/978-1-137-08228-2.

Mahoney, J. and Goertz, G. 2006. 'A tale of two cultures: Contrasting quantitative and qualitative research.' Political Analysis 14(3): 227-49. doi.org/10.1093/ $\mathrm{pan} / \mathrm{mpj} 017$.

Mazzucato, M. 2013. The Entrepreneurial State: Debunking public vs. private sector myths. London: Anthem Press.

Mettler, S. 2002. 'Bringing the state back into civic engagement: Policy feedback effects of the G. I. Bill for World War II veterans.' American Political Science Review 96(2): 351-65. doi.org/10.1017/S0003055402000217.

Moore, M. H. 2013. Recognizing Public Value. Harvard, MA: Harvard University Press.

Newman, J. 2014. 'Measuring policy success: Case studies from Australia and Canada.' Australian Journal of Public Administration 73(2): 192-205. doi.org/ 10.1111/1467-8500.12076.

New Zealand Parliament 2007. New Zealand Parliamentary Debates (12 June) 639, 9759. Available from: www.parliament.nz/en/pb/hansard-debates/rhr/ document/48HansD_20070612_00001019/motions-nuclear-free-legislation20th-anniversary.

Offe, C. 1984. 'Ungovernability: On the renaissance of conservative theories of crisis.' In J. Habermas (ed.), Observation on 'The Spiritual Situation of the Age.' Cambridge, MA: MIT Press. 


\section{SUCCESSFUL PUBLIC POLICY}

Oppermann, K. and Spencer, A. 2016. 'Telling stories of failure: Narrative constructions of foreign policy fiascos.' Journal of European Public Policy 23(5): 685-701. doi.org/10.1080/13501763.2015.1127272.

Patashnik, E. 2008. Reform at Risk. Princeton, NJ: Princeton University Press.

Pressman, J. L. and Wildavsky, A. 1973. Implementation. Berkeley, CA: University of California Press.

Rose, R. 1979. 'Ungovernability: Is there fire behind the smoke?' Political Studies 27(3): 351-70. doi.org/10.1111/j.1467-9248.1979.tb01209.x.

Rothstein, B. 2011. The Quality of Government: Corruption, social trust and inequality in international perspective. Chicago: University of Chicago Press. doi.org/10.7208/chicago/9780226729589.001.0001.

Schram, S. and Soss, J. 2001. 'Success stories: Welfare reform, policy discourse, and the politics of research.' The ANNALS of the American Academy of Political and Social Science 577(September): 49-65. doi.org/10.1177/00027 1620157700105.

Schuck, P. H. 2014. Why Government Fails So Often. Princeton, NJ: Princeton University Press.

Scott, J. C. 1998. Seeing Like A State: How certain schemes to improve the human condition have failed. New Haven, CT: Yale University Press.

Selznick, P. 1949. TVA and the Grass Roots. Berkeley, CA: University of California Press.

Shergold, P. 2015. Learning from Failure: Why large government policy initiatives have gone so badly wrong in the past and how the chances of success in the future can be improved. Canberra: Australian Public Service Commission.

Stone, D. 2001. Policy Paradox: The art of political decision making. Rev. edn. New York: Norton.

Van Assche, K., Beunen, R. and Duineveld, M. 2011. 'Performing success and failure in governance: Dutch planning experiences.' Public Administration 90(3): 567-81. doi.org/10.1111/j.1467-9299.2011.01972.x.

Van den Bos, K., Van der Velden, L. and Lind, E. A. 2014. 'On the role of perceived procedural justice in citizens' reactions to government decisions and the handling of conflicts.' Utrecht Law Review 10(4): 1-26. doi.org/10.18352/ ulr.287. 
Weisburd, D., Farrington, D. P. and Gill, C. with Ajzenstadt, M., Bennett, T., Bowers, K., Caudy, M. S., Holloway, K., Johnson, S., Lösel, F., Mallender, J., Perry, A., Tang, L. L., Taxman, F., Telep, C., Tierney, R., Ttofi, M. M., Watson, C., Wilson, D. B. and Wooditch, A. 2017. 'What works in crime prevention and rehabilitation: An assessment of systematic reviews.' Criminology and Public Policy 16(2): 415-49. doi.org/10.1111/1745-9133.12298.

Wildavsky, A. 1987. Speaking Truth to Power: The art and craft of policy analysis. New Brunswick, NJ: Transaction Books. 
This text is taken from Successful Public Policy: Lessons from Australia and New Zealand, edited by Joannah Luetjens, Michael Mintrom and Paul 't Hart, published 2019 by ANU Press, The Australian National University, Canberra, Australia.

doi.org/10.22459/SPP.2019.01 